УДК 81.161

DOI https://doi.org/10.26661/2414-1135-2021-82-12

\title{
ПЕРЕКЛАД ЛІНГВОКРАЇНОЗНАВЧИХ РЕАЛІЙ
}

\author{
Дуда О. I. \\ кандидат філологічних наук, доцент, \\ доцент кафедри іноземних мов та інформаційно-комунікаційних технологій \\ Західноукраїнський національний університет \\ вул. Львівська, 11, Тернопіль, Украӥна \\ orcid.org/0000-0003-1586-8884 \\ OleksandraHor@i.ua \\ Рибачок С. М. \\ кандидат філологічних наук, доиент, \\ доиент кафедри іноземних мов та інформаційно-комунікаційних технологій \\ Західноукраӥнський національний університет \\ вул. Львівська, 11, Тернопіль, Украӥна \\ orcid.org/0000-0002-8428-640X \\ rybachok@wunu.edu.ua
}

\author{
Ключові слова: \\ перекладознавство, \\ національно-культурний \\ компонент, транскрипція, \\ описова перифраза, \\ калькування.
}

У сучасних умовах глобалізації для пошуку порозуміння та толерантності особливого теоретичного і практичного значення в перекладознавстві набуває питання відтворення національно-культурних особливостей мови, зокрема лінгвокраїнознавчих реалій. Реалії - особливі мовні одиниці, які вербалізують унікальні національно-культурні явища, притаманні певному етносу, народності, і які відсутні в інших, що спричинює проблеми для пошуку еквівалентних шляхів відтворення їх мовою перекладу.

Метою статті є 3'ясувати сутність поняття реалії та виявити основні способи відтворення англомовних лінгвокраїнознавчих реалій українською мовою на прикладах фактів із різних аспектів національної культури англомовних країн. Матеріалом дослідження є англомовні лінгвокраїнознавчі тексти.

У статті описано такі основні шляхи відтворення реалій у лінгвокраїнознавчих текстах, як транскрипція, калькування, описова перифраза та контекстуальне тлумачення, гіперонімічне перейменування. Транскрипція як одне 3 найважливіших засобів передає фонетичне звучання реалії 3 англійської мови в перекладацьку та національні особливості антропонімів та топонімів. Калькування відтворює реалії шляхом буквального перекладу структурно-семантичних моделей мови-джерела засобами мови-перекладу. Транскрипція та калькування поєднуються 3 описовою перифразою - комбінованою реномінацією - ефективним, хоча й багатослівним засобом передачі змісту реалії, пов'язаного з лінійним розширенням тексту. Відтворення реалій гіперонімічним перейменуванням може супроводжуватися втратою певної лінгвокраїнознавчої та культурологічної інформації, адже конкретне поняття передається лексемою широкої референції. Контекстуальне тлумачення реалій $є$ засобом створення особливого географічно-історично-культурного фону в лінгвокраїнознавчих текстах. 3 огляду на унікальність та чужорідність відтворюваних явищ ефективними засобами для трансляції змісту реалій є транскрипція 3 метою передачі звучання слова та описова перифраза для досягнення високого ступеня експліцитності. 
TRANSLATING LINGUISTIC AND COUNTRY REALIAS

\author{
Duda O. I. \\ Candidate of Philological Sciences, Associate Professor, \\ Associate Professor at the Department of Foreign Philology \\ West Ukrainian National University \\ Lvivska str., 11, Ternopil, Ukraine \\ orcid.org/0000-0003-1586-8884 \\ OleksandraHor@i.ua \\ Rybachok S. M. \\ Candidate of Philological Sciences, Associate Professor, \\ Associate Professor at the Department of Foreign Philology \\ West Ukrainian National University \\ Lvivska str., 11, Ternopil, Ukraine \\ orcid.org/0000-0002-8428-640X \\ rybachok@wunu.edu.ua
}

Key words: translation studies, national and cultural component, transcription, descriptive periphrasis, linguistic calque.
Translating of the national and cultural concepts represented by linguistic and country realias presents particular theoretical and practical significance in translation studies and requires a special attention in globalization processes for understanding and tolerance.

The paper aims at scrutinizing the meaning of realia as means of representing of national and cultural concepts through translation point of view and to identify the ways of reproducing English linguistic and country realias in the Ukrainian language. The material of the research is English-language linguistic and country study texts.

Realies are linguistic units that verbalize unique national and cultural concepts inherent in a particular ethnic group, nationality, and which are absent in other cultures, which causes problems in finding equivalent ways to reproduce them in the translation language. The article describes the effective ways of reproducing realities from the source language (SL) into translation language (TL) such as transcription, linguistic calque, descriptive periphrasis contextual interpretation, and hyperonymic renaming in linguistic and cultural texts. Transcription is one of the effective means to reproduce the phonetic sounds of realias from the source language into the translation language and transfer national features of anthroponyms and toponyms. Linguistic calque reproduces realities by literally translating structural and semantic models of the SL by means of the TL. Transcription and linguistic calque are combined with descriptive periphrasis as an effective means of conveying the meaning of realia associated with the linear expansion of the text. Reproduction of realias by hyperonymic renaming may be accompanied by the loss of certain linguistic and cultural information, because a particular concept is reproduced by means of broad reference. Contextual interpretation of realias is a means of creating a special geographical, historical and cultural background in linguistic and country study texts.

The effective means to reproduce the uniqueness and foreignness of national and cultural concepts represented by realias are transcription to convey the phonetic sounds of a word and descriptive periphrasis to achieve a high degree of explicitness. 
Постановка проблеми. У сучасних умовах глобалізації для пошуку порозуміння та толерантності особливого теоретичного і практичного значення в перекладознавстві набуває питання відтворення національно-культурних особливостей мови, зокрема лінгвокраїнознавчих реалій. Такі мовленнєві одиниці $€$ яскравим вираженням географічних, історичних, культурних, цивілізаційних та інших чинників країни, мову якої вивчають, та саме вони підкреслюють культурну зумовленість змістового плану мовленнєвої одиниці, історичну, соціальну, національну співвіднесеність її з явищами певної культури, знаннями i розумінням ментальності народу.

Мета статті - 3'ясувати сутність поняття реалії та виявити основні способи відтворення англомовних лінгвокраїнознавчих реалій українською мовою на прикладах фактів із різних аспектів національної культури англомовних країн. Матеріалом дослідження є лінгвокраїнознавчі тексти.

Предмет та об'єкт дослідження. Предметом дослідження $є$ способи відтворення лінгвокраїнознавчих реалій українською мовою на прикладі текстів лінгвокраїнознавчого змісту. Об'єктом дослідження $є$ мовні реалії в англійській лінгвокраїнознавчій літературі та їхні національно-культурні особливості.

Виклад основного матеріалу дослідження. Можливості виявити особливості мови та ії способів відтворення життя народу, нації, країни а також осмислення феномена культури як специфічної форми існування людини у світі спричинили розвиток лінгвокраїнознавства, лінгвокультурології, етнолінгвістики та інших мовознавчих наук.

Питання визначення, класифікації та способів перекладу національно-культурної лексики є актуальними донині та потребують подальшого філологічного осмислення та систематизації. Узагальненим визначенням національно-культурної лексики можна вважати такі мовні одиниці, які відображають національні та культурні особливості життя, світобачення певного етносу, національної лінгвокультурної спільноти, країни, що є важливими для розуміння лінгвокраїнознавчих, лінгвокультурологічних та перекладознавчих аспектів мови, що вивчається.

Реалію як термін перекладознавства, як складник національно-культурного контексту почали досліджували 3 початку 50-х років минулого століття. Особливий внесок у дослідження реалій зробили такі дослідники, як А. Федоров, який вказував на реалію як позалінгвальне явище, О. Кундзіч, який вжив цей термін вперше в українському перекладознавстві, підкреслюючи при цьому неперекладність реалії, Г. Шатков, який визначив власні назви, які позначають національно специфичні реалії, найтиповішою безеквівалентною лексикою та ін. [4].
Визначаючи реалії як перекладознавчий термін, дослідники лінгвокраїнознавчої теорії слова Є.M. Верещагіна та В.Г. Костомаров вказували на національно-культурний інформаційний потенціал лексичного значення мовних одиниць, певної етнокультурної інформації, чужої для об'єктивної дійсності іншої мови [1]. До поняття реалій дослідники зараховували слова, словосполучення й фразеологізми та виокремлювали такі семантичні групи: історичні, побутові чи етнографічні реалії. В. Виноградов називає реаліями факти історії та державного устрою національної спільноти, особливості іiі географічного середовища, характерні предмети побуту минулого і сьогодення та зараховує їх до класу безеквівалентної лексики.

Відомі дослідники С. Влахов і С. Флорин вважали реаліями слова і словосполучення народної мови, які відображають найменування предметів, понять, явищ, характерних для географічного середовища, культури, матеріального побуту або суспільно історичних особливостей народу, нації, країни, племені, і які, таким чином, постають носіями національного, місцевого або історичного колориту; точних еквівалентів в інших мовах такі слова не мають, а отже, не можуть бути перекладені «на загальних основах», тому що вимагають особливого підходу» [2].

Водночас деякі дослідники вживають також терміни cultural words на позначення культурно маркованих слів, які є термінами країнознавства, а не перекладознавства. Український перекладознавець I. Корунець уникає терміна «реалія» та використовує узагальнений полісемантичний вислів «units of nationally biased lexicon» [5].

Деякі автори лінгвокраїнознавчих посібників класифікують реалії словом terms. Спостерігається певна спорідненість реалій та термінів як мовних знаків на позначення певних понять наукової та професійної сфери. Наприклад, Tipis - загальновживана назва для традиційного переносного житла кочових індіанців Великих рівнин, яке часто називають вігвамом. Однак за походженням терміни і реалії відрізняються між собою. Реалії виникають у народній творчості, а терміни створюють науковці та спеціалісти. Сукупність термінів із певної галузі становить єдине ціле - терміносистему [4, с. 69]. Отже, терміни є мовними одиницями, властивими науковому стилю, реалії - в художній літературі, усному мовленні.

Особливий внесок у дослідження реалії як перекладознавчого терміна на матеріалі англомовних перекладів української прози належить відомій українській дослідниці, знаному філологу та перекладознавцю, авторці книги «Реалія і переклад» професорці Р. Зорівчак. У цій праці використовуємо перекладознавче визначення реалії, запропоноване цим науковцем: «Реалії - це моно- 
і полілексемні одиниці, основне лексичне значення яких вміщає традиційно закріплений за ними комплекс етнокультурної інформації, чужої для об'єктивної дійсності мови-сприймача» [4, с. 58], в якому дослідниця вказує на реалію як категорію змінну, відносну при бінарному контрастивному зіставленні мов і культур, так, обсяг реалій мови-джерела змінюється залежно від словникового складу цільової мови, особливостей матеріальної та культури сприймача, від інтенсивності культурних та етнічних контактів.

Отже, реалія є словесною одиницею, словом, словосполученням чи фразеологізмом, яке має національно, культурно та історично закріплене значення, що за семантикою можна виокремити історичні, побутові та етнографічні складники. Виявляється реалія лише шляхом порівняння мов та культур і характеризується тим, що не існує в оточуючому світі мови-сприймача $[4$, с. 61$]$.

Найчастіше дослідники вдаються до предметної/тематичної зовнішньої, позамовної класифікації реалій, і найгрунтовніше їх дослідили С. Влахов та С. Флорин. Науковці описували реалії за предметною ознакою та місцевою ознакою (залежно від національної та мовної залежності). Професор P. Зорівчак наголошує на історико-семантичному та структурному підходах та виокремлює такі типи реалій, як неологізми, історизми, архаїзми, що потребують індивідуального підходу в процесі перекладу [4, с.70].

Аналіз англомовних текстів лінгвокраїнознавчого змісту дає змогу виокремити такі тематичні групи реалій, включно 3 антропонімами та топонімами.

1. Етнографічні реаліі:

- національні страви та напої: Welsh rarebit, Bangers, Toad in the hole, Haggis; Irn Bru; Turkey Day;

- предмети одягу, прикраси: tartan, plaid; busbies;

- особливості побуту: Welsh love spoons; mushing, tipis, igloos;

- види транспорту: the Transportation ships, Inuit sled dogs;

- спорт: cnapan, hurling;

- природа та тварини: Uluru, Tasmanian devil, the kiwi.

2. Історичні реалії на позначення військових та історичних подій: Offa's Dyke wall, Hadrian's Wall, The Klondike gold rush.

3. Географічні реалії: Albion, Alba, New France, Vinland de Good.

4. Соціоетнокультурні реаліі, наприклад, легенди, казки, міфи, пісні, гімни, танці: Eisteddfod, Cymru am byth, Haka, The Welsh dragon.

5. Суспільно-політичні реаліі: Luddites, Fathers, The Boston tea party.
Ускладнення пошуку відповідних змісту реалій зумовлені відсутністю в мові перекладу явищ, які відображають реалії дійсності в мові носіїв, а звідти і відсутність відповідності (еквівалента, аналога) через відсутність явища, який ця реалія вербалізує. Додаткові складнощі зумовлені відтворенням національно-культурної семантики реалії, що потребує додаткового осмислення, та доволі бідним представленням реалій у тлумачних та перекладних словниках.

У перекладознавчій літературі описано різні шляхи трансляції змісту реалій. В. Виноградов узагальнив такі чотири типи відтворення реалій: транскрипція (транслітерація), гіпонімічний переклад, уподібнення, дескриптивна перифраза [4, с. 92]. С. Флорин та С. Власов виділяли такі засоби передачі реалій, як транскрипція (транслітерація), переклад (заміна) різними типами неологізмів, приблизний переклад - відповідність за родом та видом, функціональний аналог, контекстуальний переклад [2, с. 87]. Р. Зорівчак описує транскрипцію (транслітерацію), гіперонімічне перейменування, дескриптивну перифразу, комбіновану реномінацію, калькування, метод уподібнення, контекстуальне розтлумачення реалій, ситуативний відповідник.

Розглянемо основні способи відтворення реалій на матеріалі лінгвокраїнознавчих текстів більш докладно.

Транскрипція реалії передбачає передачу фонетичного звучання мови 3 іноземної мови в перекладацьку графічними засобами останньої 3 максимальним наближенням до оригінальної форми (на відміну від транслітерації, яка є механічною передачею літер англійського слова засобами українського алфавіту). Такий спосіб відтворення реалій доречно використовувати для передачі національних особливостей антропонімів та топонімів: Albion - Альбіон, Celts - кельти, Helloween - Хелоувін. Разом із тим дослідники вказують на небажаність та неприпустимість втрати семантичної та експресивної значущості в процесі транскрибування. Так, транскрибування слова leprechauns - лепрекон не дає розуміння читачу описуваного явища та потребує додаткового тлумачення.

Найчастіше транскрипція поєднується 3 описовою перифразою - комбінованою реномінацісю - ефективним, хоча й багатослівним засобом передачі змісту реалії, пов'язаного з лінійним розширенням тексту, наприклад: Alba - Альба, назва Шотландї, leprechauns - лепрекон, лісовий дух, шьо здійснює бажання; Luddites - лудіти, противники технічного прогресу; Cocknеу - кокні, житель Лондона, представник нижчих сочіальних верств, Нака - хака, ритуальний танець новозеландського племені Маорі. 
Іншим методом відтворення реалій $є$ гіперонімічне перейменування - засіб, пов'язаний із визнанням частини та цілого, генералізацією, наприклад: tartan - шотландський нащіональний одяг із картатої тканини. Однак часто таке відтворення супроводжується втратою певної лінгвокраїнознавчої та культурологічної інформації, адже конкретне поняття передається лексемою широкої референції, наприклад, у кельтських орнаментах тартанів закладалася інформачія про клан - різна кількість клітинок та їх рядів визначала суспільний стан.

Калькування - це спосіб відтворення реалій шляхом буквального перекладу структурно-семантичних моделей мови-джерела засобами мови-перекладу. Розрізняють повне та часткове калькування. У разі повного калькування слова та словосполучення повністю збігаються як у структурному, так і семантичному планах. Наприклад, the War of the roses - Війна троянд, Iron Lady Залізна ледi, Holly Grail-святий Грааль. Часткове калькування включає певне тлумачення, адже калька як мовний знак особливого характеру, що позначає реалію, відсутню в поняттєвій області народу-сприймача, має вказувати на специфічність явища та виключати помилкове ототожнення 3 іншими відомими явищами [4, с. 129]. Крім того, спостереження показують, що межу між комбінованою реномінацією, гіперонімічним перейменуванням та частковою калькою перекладу провести інколи нелегко. Наприклад,

Hadrian's wall - стіна Гадріана, римський вал, побудований за наказом римського полководия Гадріана, щоб вберегти північну частину Англії від нападу кельтських племен;

Burns night/ Burns supper - вечір Бернса, ввечері 25 січня шотландиі святкують день народження шотландського поета Роберта Бернса.

Україномовний читач для адекватного розуміння таких реалій потребує описової перифрази для пояснення позамовної дійсності.

Метод уподібнення або «субституції» уможливлює переклад реалії відповідним аналогом мови-перекладу: duke - гериог, князь, donuts - naмпушки. Однак у разі таких замін стираються стилістичні та національно-культурні особливості та виникає відчуття перенесення читача в рідне середовище. А мистецтво перекладу, зазначає P. Зорівчак, в тому і полягає, що читач має завжди відчувати певну «чужинність» перекладного твору, певний національний колорит [4, с. 136-137].

Контекстуальне тлумачення реалій пов'язано 3 відтворенням семантико-стилістичних функцій тексту та роз'яснення змісту реалії в найближчому контексті. Наприклад, автори текстів із лінгвокраїнознавства, підкреслюючи особливість географічного розміщення Австралії у протилежній півкулі, використовують британську розмовну назву
Австралії Down Under - в іншій стороні світу (nід нами). Також для тлумачення назви реалії та створення картини відмінної та унікальної частини світу автори наводять приклад, що потребує контекстуального впровадження цієї реалії і в контекст мови перекладу, із книги B. Bryson «Down Under»: Australia is the driest, flattest, hottest, most desiccated, infertile and climatically aggressive of all the inhabited continents... In fact, Australia has more things that can kill you in a nasty way than anywhere else very [3, c. 367].

Отже, контекстуальне тлумачення реалій є засобом створення особливого географічно-історично-культурного фону в лінгвокраїнознавчих текстах.

Висновки. Реалії є особливими мовними одиницями, які вербалізують унікальні національно-культурні явища, притаманні певному етносу, народності, і які відсутні в інших, що спричинює проблеми для пошуку еквівалентних шляхів відтворення їх мовою перекладу. 3 огляду на унікальність та чужорідність відтворюваних явищ, для трансляції реалій використовуються транскрипція 3 метою передачі звучання англійського слова та описова перифраза для досягнення високого ступеня експліцитності. Перспективними є подальші дослідження лексикографічних аспектів англомовних реалій.

\section{ЛІТЕРАТУРА}

1. Верещагин Є.М. Лінгвокраїнознавча теорія слова. Москва, 1980. 320 с.

2. Влахов С., Флорин С. Непереводимое в переводе. Москва, 1980. 343 с.

3. Гапонів А., Возна М. Лінгвокраїнознавство. Англомовні країни. Вінниця, 2018. 452 с.

4. Зорівчак Р. Реалія і переклад ( на матеріалі англомовних перекладів української прози). Львів, 1989, 216 с.

5. Корунець І.В. Теорія і практика перекладу. Нова книга, 2003, 448 с.

6. McDowall D. An Illustrated History of Britain. Longman Group UK Limited, 2003. 192 p.

\section{REFERENCES}

1. Vereshhagyn Ye.M. (1980) Lingvokrayinoznavcha teoriya slova [Linguistic and cultural theory of a word]. $320 \mathrm{p}$.

2. Vlaxov S., Floryn S. (1980) Neperevodymoe v perevode [Untranlating in translation]. $343 \mathrm{p}$.

3. Zorivchak R. (1989) Realiya i pereklad [Realia and translation]. $216 \mathrm{p}$.

4. Gaponiv A., Vozna M. (2018) Lingvokrayinoznavstvo. Anglomovni krayiny [Linguistic and country studies. English speaking countries]. 452 p.

5. Korunets I. (2003) Teoriia i praktyka perekladu [Theory and practice of translation]. Nova knyha, $448 \mathrm{p}$.

6. McDowall D. An Illustrated History of Britain. Longman Group UK Limited, 2003. 192 p. 